\begin{tabular}{lllll}
\hline LEK. SIROV. & God. XXXV & Broj 35 & Str. 37-51 & Beograd 2015. \\
LEK. SIROV. & Vol. XXXV & No. 35 & Pp. 37-51 & Belgrade 2015. \\
\hline
\end{tabular}

Pregledni rad - Review paper

Rukopis primljen: 15.12 .2015$.

UDC: 635.7-293.5; 632.935.7:632.51

COBISS.SR-ID 220240140

Prihvaćen za publikovanje: 18.12 .2015$.

\title{
MULCHING AS A PHYSICAL WEED CONTROL METHOD APPLICABLE IN MEDICINAL PLANTS CULTIVATIONS
}

\author{
Ana Matković ${ }^{1}$, Dragana Božić ${ }^{2}$ Vladimir Filipović ${ }^{1}$, Dragoja Radanović ${ }^{1}$, \\ Sava Vrbničanin ${ }^{2}$, Tatjana Marković ${ }^{1}$ \\ ${ }^{1}$ Institute for Medicinal Plant Research "Dr J. Pančić", Tadeuša Košćuška 1, Belgrade, Serbia \\ ${ }^{2}$ University of Belgrade, Faculty of Agriculture, Nemanjina 6, Belgrade, Serbia.
}

\section{SUMMARY}

Physical methods for weeds suppression in cultivation encompass many methods but our article focuses on application of various mulches. They belong to integrated non-chemical weed management strategies and are very useful in organic farming. Mulching might be performed either by the use of biodegradable mulching materials or by various mulch films. The main benefits of organic mulches are that they can be collected from the nature, thus providing cheaper crop production. In addition, they use to be biodegradable and with no harmful effects on environment. Physical methods of weed control can cause both, positive and negative effects; they certainly influence weed suppression leading to a higher yield of cultivated herbs and vegetables but if applied as living mulches in a main crop production, they compete for essential resources. In addition, apart from the weeds, living cover crop at the same time also suppress the main crop. Therefore, a great attention should be paid when selecting the most appropriate living mulch for the purpose of weed suppression in any specific cultivation. In this article, experiences with various biodegradable mulches (straw, chopped newspapers, biodegradable and photodegradable films, gravel and compost) are well described, with a special attention devoted to their use in cultivation of medicinal plants. Presented data support application of physical methods of weeds control in cultivated crops and suggest them as efficient for use in cultivation of medicinal plants.

Key words:physical methods, weeds, mulch film, mulch, medicinal plant cultivation. 


\section{INTRODUCTION}

Physical methods for weeds suppression are the methods suggested by integrated non-chemical weed management strategy and are very useful in organic farming. Cultivation ofmedicinal plantsrelies onorganic productionand usually followsits principles [1].

There are disagreements in the interpretation of physical methods for weeds control. Hatcher and Melander [2] discussed four physical and cultural methods: mechanical, thermal, cutting and intercropping, while Bond and Grundy [3] discussed non-chemical weed management, focusing on traditional methods (mechanical and thermal) and the use of mulches which they considered physical since it physically suppresses weeds [4]. In addition, mechanical methods have many options since it uses different tools in inter-row cultivation (hoeing, harrowing, brushing) and intra-row cultivation (finger weeder, torsion weeder, split hoe, steering hoe) $[3,5]$. One of the most extensive descriptions of the physical methods have been proposed by Bond et al. [6], and according to them, physical methods encompass mechanical, pneumatic and thermal weed control as well as mulching; mechanical methods might include cultivating tools such as hand tools, harrows, tractor hoes, brush weeders, mowers, cutters and strimmers, while thermal weed control appertain on flame weeding, infrared radiation, freezing, steaming, direct heat, electrocution, microwaves, electrostatic fields, irradiation, lasers, ultraviolet light and solarisation. On the other hand, hand-weeding or hoeing during a crop growth, as one of the oldest physical methods of agricultural weed management, require professionally trained labour. Thus, in order to reduce the amount of weeds up to the acceptable level, some authors [7] suggested combining manual weeding with mechanical inter-row weeding, while other authors [8] more focused to reduction of the labour, suggesting combining the cultural and physical methods.

Medicinal and aromatic plants (MAPs) represent part of the wild flora with a large number of species in Serbia. The secondary metabolites which they produce are commonly used in the food, pharmaceutical and cosmetic industries. Increasing demands can no longer be satisfied from the nature since many resources become seriously endangered, in addition to the fact that the entire procedure is getting more and more complicated. Thus, interest in cultivating the most significant MAP species is rapidly expanding and evolving as the only solution. However, one of the main problems in MAP cultivations are the weeds; apart that they diminish quantity of produced herbal material they also interfere with mechanized harvest and alter the final quality of row material [9-11].

In this paper, the importance of physical methods for weed suppression is emphasised. However, obvious disagreement in the literature regarding division of physical methods in weed control leaded the authors to focus only on mulching 
methods in weed control, since it is acceptable in organic farming, require low involvement of human labour and can be applied in MAP cultivation.

\section{MULCHINGIN WEED CONTROL}

The principle aim of mulching is to cut off the light to the weeds and to suppress their growth [12-14]. Since every type of the mulch covers soil and performs physical pressure to the weeds, the authors of this paper divided them into two main groups, living and non-living mulches.

\section{Living mulches}

Living mulches encompass plants grown in the field for various ecological benefits of the main crop but are not the main crop. They are capable to influence diseases, pests and soil organisms, and can also serve to control weeds. Apart from weeds suppression, advantages of the use of living mulches also include efficient control of erosion, reduction of nitrate leaching, better soil structure and improved pest and disease self-regulation. The living mulch concept has been tested with a number of typical row crops, such as maize [15], sunflower [16], soybeans [17], cabbage [18], broccoli [19] and strawberry [20], but the emphasis has been given to leguminous plants, especially the white clover (Trifolium repens).

A main crop and a living cover crop compete for essential resources, while the living cover crop at the same time suppresses both, the main crop and weeds. In the frame of some researches with legumes, the yield of soybean was suppressed by Medicago spp. [17], while the growth of Trifolium repens reduced the yield of both, the cabbage and weeds [18]. Experiments on suitability of medicinal plants carried out in field conditions confirmed the importance of weed competition and benefits of living mulches [21]. Many other researchers [3,22-24] claimed that living mulches are useful tool for weed suppression in sustainable agricultural systems and suggested their use as an alternative ecological method to chemical and mechanical weed control, which can be used in combination with other cultural methods.

Generally, for every weed suppression method, the life cycle and the growth stage of weeds seem to be very important. Teasdale et al. [24] presented potential impact of typical living cover crop on weeds inhibition in some of their growth stages and concluded that the impact on weed growth is very high.

The successful living mulch is supposed to provide minimal competition with the main crop for light, water and nutrients. If planted between the rows, it might reduce presence of weeds and limit weed seed production [25] and prevent or at least retard its germination [24]. Application of living mulches hold potential 
to reduce soil erosion, get better water filtration and lower weed pressure [26], but equilibrium between the main crop and plant species that serve as living mulch must exist [27]. This balance might be achieved by selecting species with different phenology [28] or different planting time [25] compared to the main crop. On the other hand, a legume living mulch use to be applied in order to provide a constant and sufficient supply of nitrogen [29] and better conditioning of the main crop, thus creating circumstances in which the main crop is more competitive compared to the intercrop species.

\section{Non-living mulches}

Non-living mulches are mulches made of non-living plant material. They might be either mechanically incorporated in the soil, or they can be treated with some chemicals or left on the soil after mowing to naturally dry, prior to be used. Nowadays, interest in chemical weed control in MAPs cultivation is low because their cultivation increasingly involves methods that are identical or at least in accordance to the organic ones, and include application of various mulching materials and omission of synthetic herbicides. In addition, such methods can be used only between the rows of cultivated crop.

Mulches are commonly used in cultivations of vegetables and MAPs and are acceptable in organic farming [30], as well as in any other crop production that requires reduced use of pesticides. Applying mulches after planting the main crop or before the weeds start to germinate, certainly bring about many benefits to cultivated crops. Mulches have significant influence on the soil moisture and temperature, interfere with the light availability to the main crop, and since their application diminishes weed competition, they create better conditions for development of the grown crop [13, 31-35].

Differences in efficacy of various non-living mulches mainly appear due to the type of mulches used, the tackiness of mulch layer, as well as due to the uniformity of its distribution [34-36]. According to our previous experiences [35], even the thickness of two different mulches is identical, their efficacy in weeds suppression significantly differed; the mulch made of straw and the one made of sawdust differently stop passage of the light to the soil surface, thus giving different chances to the weeds to germinate and further proceed with development. Consequently, it is obvious that the major part of attention should be paid on extending the period of soil coverage, since it is proved to be directly correlated to the weeds suppression [35].

Good soil coverage and related mulch efficacy certainly depend of the type of mulches applied. The non-living mulches could be made of eather biodegradable material (often cheaper but less effective) or in the form of non-biodegradable film (has to be removed from the crop establishment once they are not useful anymore). 


\section{Biodegradable mulches}

Biodegradable mulches are "organic recovery", since they represent the most commonly applied waste reduction methods. They can be tilled in by the end of the season, thus resulting in reduction of the labour cost for weed suppression.

In various vegetable cultivations, many investigations have been conducted with application of straw mulches; Jodaugiene et al. [37] reported results in cultivation of bean and onion whereas Ramakrishna et al. [32] studied it on the groundnut. Radics and Bognár [38] and Grassbaugh et al. [39] examined mulches used in cultivation of tomatoes, Döring et al. [40] in potatoes, whereas Jenni et al. [41] in lettuce produced on organic soils. Sinkevičienè et al. [42] studied the efficacy of biodegradable mulches in onions, red beets, cabbages, and potatoes, while Filipović et al [43] reported results of using them in carrots.

Although the occurrence of some perennial and annual weeds proved to be dependent on the thickness of applied straw mulch, the percentage of the weeds in all cases was reduced [30]. Since the straw mulch could be made of residues of different plant species, some scientists devoted their research to efficacy of various kinds of it. The straw made of wheat residues is considered for the outstanding one $[13,39,44-46]$, while some other straw mulches are also well known: the straw mulch made of the residues of the maize, rapeseed and rye [46], the one made from the remainings from the rice [47] or MAP fields [48].

Since it is well know that MAP species possess secondary metabolites, there are many attempts to use either their isolated products (essential oils) to prevent germination of the weeds [49] or to use their remainings in order to compose mulches with strong weed-supressing activity. Kamariari et al. [45] used mulch composed of two MAP species (Sideritis scardica and Echinacea purpurea) in maize cultivation and reported significantly lower weed biomass. Ram and Kumar [51] studied efficacy of Cymbopogon sativum post distillation waste mulch and Pisum sativum straw mulch in mint (M. arvensis) cultivation; the application of citronella mulch resulted in higher herb and essential oil yields, with no effect on the quality of the oil obtained from the first harvest of the sucker-planted crop nor in the transplanted mint crop.

Chopped newspaper also used to serve as a raw material for mulch. Compared to the straw or any of non-biodegradable film mulches, it is cheaper and, contrary to the films mulches, can be easily plowed into the soil [45]. However, there is always risk of introducing too much of lead $(\mathrm{Pb})$ into the soil, if mulch is overused. In addition, certain environmental conditions (wind, rain, snow) cause breakdown of the paper or cardboard mulches $[12,52]$, while even dissolved, newspapers still influence moisture and soil temperature [13].

The efficiency of paper mulches differ depending on several factors, such as the amount of applied mulch, environmental factors, weed species they are 
supposed to supress, as well as on the cultivated crop and its production technology $[45,52-53]$.

Mulching with biodegradable and photodegradable films reduces run-offs, increase penetration of rainwater, controls erosion, corrects the chemical balance of the soil and reduces damage done by pests and diseases. Apart from these major advantages, mulching also causes some secondary effects, such as improvement of the soil structure, increase of micro-activity, rise in earthworm populations, and development of more extensive root systems. Radanović et al. [54] reported that in comparison to the black and silver PE films, black permeable biodegradable mulching film (bPB) significantly influenced development and the obtained root yields of cultivated Gentiana lutea during six-year period; according to the root yields per $\mathrm{m}^{2}$, the bPB film proved to be the most effective in the $5^{\text {th }}$ and $6^{\text {th }}$ vegetation.

Carrubba and Militello [9] presented some environmentally friendly techniques for weed management, which proved to be efficient to increase seed yields of coriander, fennel and psyllium. Although biodegradable films used in experiment positively affected yields, they were not capable to suppress weeds.

Organic agriculture also uses some degradable inorganic materials, such as gravel, which has been used as mulch from almost forty years now [55]. Besides the thickness of this mulch, the gravel different grain size is also examined [56]. Wang et al. [36] investigated implementation of gravel-sand mulches in watermelon production and reported how it influences the soil temperature. There are reports on application of many other organic mulches, such as composted pine bark in Allium aflatunense [57] or pine bark mulch in Salvia splendens [58].Sawdust was recommended as effective mulch for acid-loving plants, such as calla [59] or blueberries [60-61]. Straw and other organic mulches, similarly to composting process, decompose over time through mineralization process, thus forming humus. Apart from its primary use as organic fertilizers, compost positively contribute to the soil structure and is frequently used for production of various substrates and mulches $[35,43,62]$.

\section{Non-biodegradable film mulches}

Cost effectiveness of using film mulches can be seen only in perennial plantations or in establishments with plants such as strawberries, mint or yellow gentian, where they positively affect their underground organs (stolones and roots). However, mulching has been conducted in production of the aboveground plant parts of many perennial MAPs, such as rosemary, thyme and lavender, etc. [64]. Different polypropylene (PP) black films were tested for efficiency in weed control and the results proved significant increase in the plants height [64]. Normally, black and other film colours are used in a cultivation of strawberry and watermelon, since they need higher soil temperatures for attaining desired 
sweetness. Polara and Viradiya [14] presented superior yield and quality features of watermelon produced on silver-black PE film, although it is quite known that conventional PE films create a big trouble to the environmental. With regard to this, Costa et al. [65] compared efficacy of PE film with five biodegradable films and proved no significant differences in productivity and quality of strawberry.

In MAPS, the achieved herb yields are not always of the primary importance; priority is usually given to their chemical quality and to the amount of secondary metabolites they are produced for (essential oils, alkaloids, flavonoids, etc.). Radanović et al [66] reported results of testing PE mulch films in cultivation of arnica; the film positively affected number of flowers, height of plants and rosettes diameter. The sutisfactory effects on the yield of yellow gentian roots are achieved with water permeable biodegradable film [66]. In addition, in the root production of yellow gentian, due to quite different climatic conditions, the black PE film was less efficient in Serbia [54] than in Finland [68]. Comparing to the black PE film, silver PE film prove to be more suitable for yellow gentian root production in our country [54].

Main mulching advantages and disadvantages, with accent on their weed suppression capabilities

The influence of different mulch types on crop yield might be positive or negative, related totheir weed suppression effect. Many researchers proved positive effects of mulching on crop growth and the obtained yield quantities and qualities $[32,34-35,69-71]$.

The straw mulch is one of the earliest mulches ever used [44]. It does not positively influence only the soil moisture and temperature $[12,44]$, but also the soil structure [46]. The problem is only that it is a perfect shelter for rodents and many other pests. The straw mulch is made of cut cover crop residues which are commonly used in no-till and reduced-tillage systems, when left in a field. Although this kind of mulch might be easily used from one to another field, it brings a risk of spreading weeds into a new crop establishment, including the cover crop residues. Therefore, disadvantages of this mulching model are not only infestation possibility of the new crop and emergence of both, the brought weeds and former crop [72], but also lower weed suppression efficacy in comparison to the one achieved by living mulches [73-74]. On the other hand, apart to already mentioned advantages of the straw mulch application, another great straw mulch advantage is that, unlike many other mulches, this one can be easily plowed when no longer needed. For instance, the main problem for the gravel mulch application is its removal from plantation; therefore it is preferably used in a city parks since it is water conductive and serve there as an excellent weed suppressant for many years. Using a compost as a mulch intended for weed suppression is somehow contradictory as it is proved that survival of the seeds of most weeds is extremely 
high [62]. It can act only with physical pressure, at the same time releasing nutrients for the main crop.

Regardless the colour, non-biodegradable PP and PE films mulches proved to be the most efficient in preventing of germination of seeds of the most weeds and their further growth, though they are also helpful in preventing loss of the moisture from the soil and in balancing of its temperature [75.]. Their application frequently bring about many other benefits, such as reduction of the run-offs, increase in rain water penetration, control of erosion, correction of the chemical balance of the soil and reduction of pest and disease damages. However, they also have some environmental disadvantages, related to the removal and handling of their waste [76]. Mulching films cannot be naturally biodegrade, and they should be removed from the field. The main problem is that most farmers do not care about the film residues. Some of them use to burn them, thus producing other substances that are noxious to the environment [77]. Here are several practices recommended to use in order to reduce the negative impact of the mentioned residues, including recycling or incineration [78], though they also bring about disadvantages of the other kind. The prices of PE films are not acceptable for small producers and unlike to biodegradable films, after they are not needed anymore producers must withstand additional cost for their proper disposal. On the other hand, since film mulches are not permeable, they demand irrigation system, whose installation additionally raises the costs of entire production.

\section{CONCLUSION}

Physical methods play an important part of integrated and organic plant protection systems and apart from vegetables, they should be also regularly practiced in the row cultivation of medicinal plants. The similarities in growing medicinal herbs and vegetables are reflected in the fact that both used to be grown at small areas, the use of pesticides is very limited and the major troubles in their cultivation represent weeds. Therefore, already tested weed control methods in vegetables seem to be also recommended for application in MAP cultivation. Out of several physical methods of weed control, mulching seems to be the most appropriate one. However, further investigation should involve in-detail research of this method for possible large-scale application in several most market demanding MAP species.

\section{ACKNOWLEDGEMENT}

We are grateful to the Ministry of Education, Science and Technology of Republic of Serbia for supporting this investigation (Project III46008). 


\section{LITERATURA}

1. Radanović D., Nastovski T. (2002): Proizvodnja lekovitog i aromatičnog bilja po principima organske proizvodnje. Lekovite sirovine,22: 83-99.

2. Hatcher P. and Melander B. (2003): Combining physical, cultural and biological methods: prospects for integrated non-chemical weed management strategies. Weed Research, 43: 303-322.

3. Bond W. and Grundy A.C. (2001): Nonchemical weed management in organic farming systems. Weed Research, 41: 383- 405.

4. Ferguson J., Rathinasabapathi B., Warren C. (2008): Southern red cedar and southern magnolia wood chip mulches for weed suppression in containerized woody ornamentals. Hort Technology 18(2): 266-270.

5. Carrubba A., Verde G., Salamone A. (2013): Sustinable Weed, Disease and Pest Management in Medicinal and aromatic Plants - Chapter 11. In: Medicinal and Aromatic Plants of the World, Springer Science: pp. 205-212.

6. Bond W., Turner R., Grundy A. (2003): A review of non-chemical weed management. The organic organisation: 1-81. http://www.organicweeds.org.uk

7. Ionescu N., Perianu A., Popescu A., Sarpe N., Roibu C. (1996). Weed control in corn and soybean crops by mechanical and manual management practices. The $10^{\text {th }}$ Colloque International sur la Biologie des Mauvaises Herbes, Dijon, France. Proceedings, pp. 359-365.

8. Ascard J., Hansson D., Svensson S. (2014): Physical and cultural weed control in Scandinavia. $10^{\text {th }}$ EWRS Workshop on Physical and Cultural Weed Control, Alnarp, Sweden. Proceedings, pp. 2

9. Carrubba A. and Militello M. (2013): Nonchemical weeding of medicinal and aromatic plants. Agronomy for sustainable development, 33(3): 551-561.

10. Carrubba A., Catalano C. (2009). Essential oil crops for sustainable agriculture a review. In: Climate Change, Intercropping, Pest Control and Beneficial Microorganisms, Springer Science: 137-187.

11. Radanović D., Nastovski T. (2008): „Lekovito, aromatično bilje i šumski plodovi u organskoj proizvodnji“" u naučnoj monografiji „Organska poljoprivreda“, tom II, Babović J. i Lazić B. (eds), Naučni Institut za ratarstvo i povrtarstvo Novi Sad, str. 463-508.

12. Munn D. (1992): Comparisons of shredded newspaper and wheat straw as crop mulches. Hort Technology, 2: 361- 366.

13. Monks D., Monks D., Basden T., Selders A., Poland S., Rayburn E. (1997): Soil temperature, soil moisture, weed control, and tomato (Lycopersicon esculentum) response to mulching. Weed Technology, 11: 561-566.

14. Polara P., Viradiya R. (2013): Effect of mulching material on growth, yield and quality of watermelon (Citrullus lanatus Thunb) Cv. Kiran. Universal Journal of Agricultural Research, 1(2): 30-37. 
15. Yeganehpoor F., Salmasi, Abedi G., Samadiyan F., Beyginiya V. (2015): Effects of cover crops and weed management on corn yield. Journal of the Saudi Society of Agricultural Sciences, 14(2): 178-181

16. Amoghein B., Tobeh A., Gholipouri A., Jamaati-e-Somarin Sh., Ghasemi M. (2013): Effect of cover crop in control of weed density and some qualitative and quantitative characteristics of sunflower. International Journal of Agriculture and Crop Sciences, 5: 1318-23.

17. Sheaffer C., Gunsolus J., Grimsbo J., Lee S. (2002): Annual Medicago as a smother crop in soybean. Journal of Agronomy and Crop Science, 188: 408-416.

18. Brandsaeter L., Netland J., Meadow R. (1998): Yield, weeds, pests and soil nitrogen in a white cabbage-living mulch system. Biology, Agriculture and Horticulture, 16: 291-309.

19. Warren N., Smith R., Sideman R. (2015): Effects of living mulch and fertilizer on the performance of broccoli in plasticulture, Hort. Science, 50: 218-224.

20. UniverT., Põrk K., UniverN. (2009): Living grass mulches in strawberry cultivation. Agronomy Research 7(Special issue I): 532-535.

21. Duppong L., Delate K., Liebman M., Horton R., Romero F., Kraus G., Petrich J., Chowdbury P. (2004): The effect of natural mulches on crop performance, weed suppression and biochemical constituents of catnip and St. John's Wort. Crop Science, 44(3): 861-869.

22. Kruidhof H., Bastiaans L. and Kropff M. (2008): Ecological weed management by cover cropping, effects on weed growth in autumn and weed establishment in spring. Weed Research, 48: 492-502.

23. Kitis Y., Koloren O., Uygur F. (2011): Evaluation of common vetch (Vicia sativa L.) as living mulch for ecological weed control in citrus orchards. African Journal ofAgricultural Research, 6: 1257-1264.

24. Teasdale J., Brandsæter L., Calegari A., Skora Neto F. (2007): Cover crops and weed management. In: M.K. Upadhyaya and R.E. Blackshaw (eds.), Nonchemical weed management. CAB International, Wallingford, UK, 49-64.

25. Gibson K., McMillan J., Hallett S., Jordan T., Weller S. (2011): Effect of a living mulch on weed seed banks in tomato, Weed Technology, 25(2): 245-251.

26. Hartwig N. and Ammon H. (2002): Cover crop and living mulches. Weed Science, 20: 688-699.

27. Brainard C. and Bellinder R. (2004): Weed suppression in a broccoli winter rye intercropping system. Weed Science, 52: 281-290

28. Liebman M. and Dyck E. (1993): Crop rotation and intercropping strategies for weed management. Ecological Applications 3: 92-122.

29. Enache A., Ilnicki R. (1990): Weed control by subterranean clover (Trifolium subterraneum) used as a living mulch. Weed Technology, 4(3): 534-538.

30. Massucati L., Köpke U. (2014): Effect of straw mulch residues of previous crop oats on the weed population in direct seeded faba bean in Organic Farming. $26^{\text {th }}$ 
German Conference on weed Biology on Weed Control, Julius-Kuhn-Archiv, 443: 483-492.

31. Sharratt B. (2002): Corrn stubble height and residue placement in the Northern USCorn Belt.Part II. Spring microclimate and wheat development. Soil Tillage Research, 64: 253-261.

32. Ramakrishna A.,Tam H.,Wani S.,Long T. (2005): Effect of mulch on soil temperature, moisture, weed infestation and yield of ground nut in northern Vietnam. Field Crops Research, 95(2-3): 115-125.

33. Cook H., Valdes G. and Lee H. (2006): Mulch effects on rainfall interception, soil physical characteristics and temperature under Zea mays L. Soil Tillage Research, 91: 227-235.

34. Jodaugienè D., Pupalienè R., Marcinkevičienė A., Sinkevičienė A. (2012): Integrated evaluation of the effect of organic mulches and different mulch layer on agrocenosis. Acta Scientiarum Polonorum: Hortorum Cultus. Lublin, 11(2): 71-81.

35. Matković A., Radanović D., Marković T., Vrbničanin S., Božić D. (2015): Suzbijanje korova u pitomoj nani (Mentha $x$ piperita) primenom malčeva. Zbornik rezimea radova XIII savetovanja o zaštiti bilja, Zlatibor, 45.

36. Wang Y., Xie Z., Malhi S., Vera C., Zhang Y. (2014): Gravel-sand mulch thickness effects on soil temperature, evaporation, water use efficiency and yield of watermelon in semi-arid Loess Plateau, China. Acta Ecologica Sinica, 34(5): 261-265.

37. Jodaugienè, D., R. Pupalienè, M. Urbonienè, V. Pranckietis, I. Pranckietienè (2006): The impact of different types of organic mulches on weed emergence. Agronomy Research 4(sp. issue): 197-201.

38. Radics L., Szné Bognár E. (2004): Comparison of different mulching methods for weed control in organic green bean and tomato. Acta Horticulturae, 638: $189-196$.

39. Grassbaugh E.M., Regnier E.E., Bennett M.A. (2004): Comparison of organic and inorganic mulches for heirloom tomato production. Acta Horticulturae, 638: $171-6$.

40. Döring T.F., Brandt M., Heß J., Finckh M.R., Saucke H. (2005): Effect of straw mulch on soil nitrate dynamics, weeds, yield and soil erosion in organically grown potatoes. Field Crop Research, 94(2-3): 238-249.

41. Jenni S., Brault D., Stewart K. (2004): Degradable Mulch as an Alternative for Weed Control in Lettuce Produced on Organic Soils. Acta Horticulturae, 638: 111-118.

42. Sinkevičienė A., Jodaugienė D., Pupalienė R., Urbonienè M. (2009): The influence of organic mulches on soil properties and crop yield. Agronomy Research, 7(1): 485-491. 
43. Filipović V., Jevđović R., Dimitrijević S., Marković T., Grbić J. (2012): Uticaj primene organskih malčeva na agrofizičke osobine i prinos korena mrkve. Lekovite sirovine, 32: 37-46.

44. Unger P. (1978): Straw mulch effects on soil temperatures and sorghum germination and growth. Agronomy Journal, 70: 858-864.

45. Sanchez E., Lamont W., Orzolek M. (2008): Newspaper mulches for suppressing weeds for organic high-tunnel cucumber production. Hort. Technology, 18: 154-15.

46. Kosterna E. (2014): The effect of soil mulching with organic mulches, on weed infestation in broccoli and tomato cultivated under polypropylene fibre, and without a cover. Journal of Plant Protection Research, 54(2): 188-198.

47. Singh M. and Saini S. (2008): Planting date, mulch, and herbicide rate effects on the growth, yield, and physicochemical properties of menthol mint (Mentha arvensis). Weed Technology, 22(4): 691-698.

48. Božić D., Filipović V., Matković A., Marković T., Vrbničanin S. (2015): Effect of composting on weed seeds survival. VII Congress on Plant Protectıon, 24$28^{\text {th }}$ November, 2014, Zlatibor, Serbia. Proceedings, pp. 171-174.

49. Matković A., Božić D., Vrbničanin S., Marković T. (2016): "Effect of essential oils on germinated seeds of ragweed". $5^{\text {th }}$ International Symposium "AgroReS 2016”, Banja Luka, Feb 29 ${ }^{\text {th }}$ - March ${ }^{3 r d}$, 2016.Book of abstracts (in press).

50. Kamariari I., Papastylianou P., Bilalis D., Travlos I., Kakabouki I. (2014): The role of mulching with residues of two medicinal plants on weed diversity in maize. $4^{\text {th }}$ ISOFAR Scientific Conference 'Building Organic Bridges', at the Organic World Congress 13-15 ${ }^{\text {th }}$ October, 2014, Istanbul, Turkey. Proceedings.

51. Ram M. and Kumar S. (1997): Yield improvement in the regenerated and transplanted mint Mentha arvensis by recycling the organic wastes and manures. Bioresource Technology, 59: 141-149.

52. Weber C. (2003): Biodegradable mulch films for weed suppression in the establishment year of matted-row strawberries. HortTechnology, 13: 665-668.

53. Jodaugienė D., Marcinkevičienè A., Pupalienè R., Sinkevičienè A., Bajorienė K. (2014): Changes of weed ecological groups under different organic mulches. 26th German Conference on weed Biology an Weed Control, JuliusKuhn-Archiv, 443: 244-251.

54. Radanović D., Marković T.,Vasin J., Banjac D. (2016): The efficiency of using different mulch films in the cultivation of yellow gentian (Gentiana lutea L.) in Serbia. Ratarstvo i Povrtarstvo,53(1): doi:10.5937/ratpov53-9589

55. Fairborn M. (1973): Effect of gravel mulch on crop yield. Agronomy Journal, 65(6): 925-928.

56. Qiu Y., Xie Z., Wang Y., Ren J., Malhi S. (2014): Influence of gravel mulch stratum thickness and gravel grain size on evaporation resistance. Journal of Hydrology, 519: 1908-1913. 
57. Laskowska H., Pogroszewska E., Durlak W., Kozak D. (2012): The effect of bulb planting time and type of mulch on the yield of Allium aflatunense B. Fedtsch.Acta Agrobotanica, 65(4): 117-122.

58. Błażewicz-Woźniak M., Madej J., Rtemi D., Wartacz W. (2011): The growth and floweringof Salvia splendens Sellow ex Roem. et Schultunder flowerbed conditions. Acta Agrobotanica, 65(2): 99-108.

59. Wright P. and Burge G. (2010): Irrigation, sawdust mulch, and Enhance ${ }^{\circledR}$ biocide affects soft rot incidence, and flower and tuber production of calla New Zealand. Journal of Crop and Horticultural Science, 28(3): 225-231.

60. Haynes R. and Swift R. (1986): Effect of soil amendments and sawdust mulching on growth, yield and leaf nutrient content of highbush blueberry plants. Scientia Horticulturae, 29(3): 229-238.

61. Sanderson K. and Cutcliffe J. (1991): Effect of sawdust mulch on yields of select clones of lowbush blueberry. Canadian Journal of Plant Science, 71(4): 1263-1266.

62. Božić D., Filipović V., Matković A., Marković T., Vrbničanin S. (2015): Effect of composting on weed seeds survival. VII Congress on Plant Protection, 24$28^{\text {th }}$ November, 2014, Zlatibor, Serbia. Proceedings, pp. 171-174.

63. Matković A., Božić D., Vrbničanin S., Marković T. (2014): "Integrated weed management in medicinal plants" VII Congress on plant protection: "Integrated Plant Protection - Knowledge-Based Step Towards Sustainable Agriculture, Forestry And Landscape Architecture", 24-28 ${ }^{\text {th }}$ November, 2014, Zlatibor, Serbia. Book of abstracts, pg. 189-190.

64. Fontana E., Hoeberechts J., Nicola S. (2006): Effect of mulching in medicinal and aromatic plants in organic farm guest houses. Acta Horticulturae, 723: 405-410.

65. Costa R., Saraiva A., Carvalho L., Duarte E. (2014): The use of biodegradable mulch films on strawberry crop in Portugal. Scientia Horticulturae, 173: 65-70.

66. Radanovic D., Pljevljakusic D., Markovic T., Ristic M. (2007): Influence of fertilization model and PE mulch on yield and quality of Arnica (A. montana) at dystric cambisol. Zemljište i biljka,56: 85-95.

67. Radanovic S.D.; Antić-Mladenović B.S., Marković Lj.T., Sekulić Đ.P., Ninkov M.J. (2012): Yiled and mineral content of Yellow Gentian root (Gentiana lutea L.) grown on black water-permeable foil in organic and mineral model of fertilization. VII CMAPSEEC, 27 $7^{\text {th }} 31^{\text {st }}$ May, 2012. Subotica, Serbia. Proceedings, pg. 291-298.

68. Galambosi B. (1996): Experiences of cultivation Gentiana lutea L. in Finland. In: Atti del Convegno "Genziana e specie amaro-aromatiche. Ricerche ed. Applicazioni. Camerino, 8-10 giugno 1995. L'uomo e l'ambiente, 19: 139-142.

69. Sharma R.R., Sharma V.P., (2003): Mulch influences fruit growth, albinism and fruit quality in strawberry (Fragaria $\times$ ananassa Duch.). Fruits, 58: 221-227. 
70. Singh R., Sharma R., Goyal R. (2007): Interacting effects of planting time and mulching on "Chandeler" strawberry (Fragaria $\times$ ananassa Duch.). Scienta Horticulturae, 111: 344-351.

71. Parmar H., Polara D., Viradiya R. (2013): Effect of mulching material on growth, yield and quality of watermelon (Citrullus lanatus Thunb) Cv. Kiran. Universal Journal of Agricultural Research, 1(2): 30-37.

72. Peachey E., William R., Mallory-Smith C. (2004): Effect of no-till or conventional planting and cover crops residues on weed emergence in vegetable row crop.Weed Technology, 18(4): 1023-1030.

73. Teasdale J., Daughtry C. (1993): Weed Suppression by Live and Desiccated Hairy Vetch (Vicia villosa). Weed Science, 41: 207-212.

74. Reddy K. and Koger C. (2004): Live and killed hairy vetch cover crop effects on weeds and yield in glyphosate-resistant corn. Weed Technology, 18: 835840.

75. Momirović, N., Oljača, V.M., Dolijanović, Ž., Poštić, D. (2010): Energetska efikasnost proizvodnje paprike u zaštićenom prostoru u funkciji primene različitih tipova polietilenskih folija (PE), Poljoprivredna tehnika, 35(3): 1 - 13

76. Moreno M. and Moreno A. (2008): Effect of different biodegradable and polyethylene mulches on soil properties and production in a tomato crop. Scienta Horticulturae, 116: 256-263

77. Briassoulis D. (2006): Mechanical behaviour of biodegradable agricultural films under real field conditions. Polymer Degradation and Stability, 91: 12561272.

78. Hemphill J., Delbert D. (1993): Agricultural plastics as solid waste: What are the options for disposal? Hort.Technology, 3(1):70-73. 


\title{
FIZIČKE METODE SUZBIJANJA KOROVA KORIŠĆENJEM MALČEVA SA MOGUĆNOŠĆU PRIMENE U LEKOVITOM BILJU
}

\author{
AnaMatković ${ }^{1}$, DraganaBožić ${ }^{2}$, VladimirFilipović $^{1}$, DragojaRadanović ${ }^{1}$, \\ SavaVrbničanin ${ }^{2}$, TatjanaMarković ${ }^{1}$ \\ ${ }^{1}$ Institut za proučavanje lekovitog bilja "dr Josif Pančić", Tadeuša Košćuška 1, Beograd. \\ ${ }^{2}$ Univerzitet u Beogradu, Poljoprivredni fakultet, Nemanjina 6, Beograd.
}

\section{IZVOD}

Fizičke metode suzbijanja korova u lekovitom bilju obuhvataju veliki broj mera, a mi smo detaljnije opisali korišćenje živih malčeva i malč prostirki. Ove metode suzbijanja korova se mogu koristiti u kombinaciji sa drugim metodama $\mathrm{u}$ okviru integralnih mera suzbijanja korova, kao i u organskoj poljoprivredi. Malčiranje predstavlja prekrivanje zemljišta pri čemu se mogu koristiti biorazgradivi malčevi ili različite malč folije. Glavne prednosti organskih malčeva su te što se mogu sakupiti u prirodi i samim tim pojeftiniti proizvodnju. Pored toga, prednosti njihovog korišćenja se vide i u tome što su biorazgradive i što nemaju štetne efekte na životnu sredinu. Fizičke metode suzbijanja korova mogu da dovedu do pozitivnih efekata, s obzirom da suzbijaju korove u lekovitom bilju i povrću, pa tako doprinose povećanju prinosa. Ukoliko se koristi živi malč, koji pored pozitivnih mera suzbijanja korova može dovesti i do negativnih efekata potrošnje neophodnih materija iz zemljišta, pa se samim tim stvara kompeticija između gajene vrste i živog malča oko potrebnih materija iz zemljišta. Pored toga, živi malč može dovesti i do gušenja i smanjenja prinosa gajene vrste, a ne samo do smanjenja pojave korova. Zbog toga se mora posvetiti posebna pažnja u odabiru živog malča, da ne bi došlo do navedenih negativnih efekata. U ovom radu smo izdvojili iskustva prilikom korišćenja različitih biorazgradivih malčeva (slama, iseckane novine, biorazgradive folije, šljunak i kompost), a posebno je naglašena njihova primena u lekovitom bilju. Predstavljeni načini malčiranja, kao vrsta fizičke metode suzbijanja korova, imaju pozitivne efekte i predlaže se njihova upotreba u lekovitom bilju.

Ključne reči: fizičke metode suzbijanja korova, malč, malč folije 